\title{
From the Andes to the Rockies: Native Strawberry Collection and Utilization
}

\author{
J.F. Hancock ${ }^{1}$ and P.W. Callow \\ Department of Horticulture, Michigan State University, East Lansing, MI 48824
}

A. Dale

Department of Plant Agriculture, Ontario Agricultural College, Simcoe, Ontario, Canada N3Y 4N5

J.J. Luby

Department of Horticulture and Landscape Architecture, University of Minnesota, St. Paul, MN 55108

C.E. Finn

U.S. Department of Agriculture, Agricultural Research Service, Northwest Center for Small Fruit Research, Corvallis, OR 97330

\author{
S.C. Hokanson \\ U.S. Department of Agriculture, Agricultural Research Service, Fruit Laboratory, BARC-W, Beltsville, MD 20705 \\ Kim E. Hummer \\ U.S. Department of Agriculture, Agricultural Research Service, National Clonal Germplasm Repository, Corvallis, \\ OR 97330
}

The commercial strawberry, Fragaria xananassa Duchesne in Lamarck (Staudt, 1999), has a narrow germplasm base, even though its progenitor species have an extensive geographical range (Hancock, 1999; Luby et al., 1991). It originated about 250 years ago when a few New World clones of $F$. chiloensis (L.) Miller and F. virginiana Miller accidentally hybridized in European gardens (Wilhelm and Sagen, 1972). Thomas A. Knight began the systematic breeding of strawberries in England in 1817, but had at his disposal only a small number of native and cultivated clones. Likewise, North American genetic improvement began in the mid-1800s with a restricted group of European $F$. Xananassa cultivars, South American $F$. chiloensis, and North American F. virginiana (Darrow, 1966). The cultivars originating from this background played the predominant role in most public and private breeding programs for the next 100 years.

The majority of the genes in modern North American cultivars still comes from only seven nuclear (Hancock and Luby, 1995; Sjulin and Dale, 1987) and 10 cytoplasmic sources (Dale and Sjulin, 1990), even though at least eight native clones have been incorporated into cultivars in the last half century. These include: 1) two unnamed clones of $F$. chiloensis from the Pacific Northwest, 2) two unnamed clones of $F$. virginiana from Oregon and Alaska, 3 ) two selections of $F$. virginiana from the Rocky Mountains (Sjulin and Dale, 1987), 4) the Huachi Grande clone of $F$. chiloensis from Ecuador (Finn et al., 1998), and 5) the Del Norte clone of $F$. chiloensis from northern California (Moore et al., 1995).

Since the germplasm base of strawberries remains narrow, native germplasm can be injected into the lineage of cultivars relatively easily. However, identification of more wild clones and their use in strawberry improvement would be beneficial. We have spent the last decade cataloging horticulturally useful traits in native populations (Cameron et al., 1993; Hancock, 1999; Hancock et al., 1990; Luby et al., 1991) and utilizing that variability (Dale et al., 1993; Hancock et al., 1993). Our primary goals have been to: 1) expand the germplasm base of $F$. Xananassa by hybridizing it with elite native octoploid clones, 2) reconstruct $F$. $\times$ ananassa using these clones, and 3) develop pure $F$. chiloensis cultivars. We would also like to construct a

Received for publication 22 May 2000. Accepted for publication 13 June 2000. The cost of publishing this paper was defrayed in part by the payment of page charges. Under postal regulations, this paper therefore must be hereby marked advertisement solely to indicate this fact.

${ }^{1}$ To whom reprint requests should be addressed. E-mail address: hancock@ pilot.msu.edu "supercore" group of native $F$. virginiana and $F$. chiloensis clones that can be used by other breeders to expand their germplasm base and serve as a reference point for future collections.

\section{EXPANDING THE GERMPLASM BASE OF F. XANANASSA}

We began our work by selecting a small group of elite $F$. virginiana clones that we felt represented the range of diversity in the North American material from cool climates. These selections came from large field and greenhouse evaluations of $F$. virginiana ssp. glauca clones from the northern Rocky Mountains (Hokanson et al., 1993; Luby et al., 1992; Sakin et al., 1997) and F. virginiana ssp. virginiana clones from the central United States and Ontario, along with a few representatives of $F$. virginiana from Alaska, Alberta, New York, Pennsylvania, and western North Carolina (Dale et al., 1993; Luby and Stahler, 1993; Luby et al., 1991).

The elite selections included Hemlo 2, High Falls 22, PI 612492 , PI 612493 and PI 612497 from Ontario; LH 10-6 from Wyoming, LH 28-1, LH 39-15, LH 40-4, and PI 612501 from Montana, RH 18 from New York, PI 612496 from Alaska, PI 612498 and PI 612499 from Minnesota, and PI 612500 from Alberta. In this paper, we represent as many genotypes as possible using the PI numbers of the U.S. National Plant Germplasm System. When these were not available, we used the local CFRA numbers of the National Clonal Germplasm Repository (NCGR) at Corvallis, Ore., or the original collector's designation if the plants were not in NCGR. PI 612496, PI 612498, PI 612499, and PI 612500 are all cyclic-flowering (putative day-neutrals), resistant to black root rot caused by unknown pathogens in Minnesota, and at least partially hermaphroditic. PI 612497, PI 612498, PI 612500, and High Falls 22 have unusually large fruit for native clones, although PI 612497 may be an introgressant with cultivated material. All the Ontario clones are resistant to powdery mildew [caused by Sphaerotheca macularis (Wallr.:Fr.) Jacz. f. sp. fragariae Peries] and leaf scorch [caused by Diplocarpon earliana (Ellis \& Everh.) Wolf.], while PI 612497 is hermaphroditic, and PI 612493 and Hemlo 2 are cyclicflowering.

These elite $F$. virginiana clones were crossed by Adam Dale with a group of $F$. ×ananassa cultivars and advanced selections representing some of the major breeding populations in North America: 1) Eastern North America day-neutral-'Tribute' [U.S. Dept. of Agriculture (USDA)-Maryland], 1I3 and 251DN107 [Ontario Ministry of Food and Rural Affairs (OMAFRA)]; 2) Eastern North American short-day-'Glooscap' (Agriculture and Agifood Canada, N.S.), and 'Governor Simcoe' (OMAFRA); 3) California day-neutral-'Sea- 
scape' and 'Hecker' (Univ. of California, Davis); 4) California shortday-'Chandler' (Univ. of California, Davis); 5) Pacific Northwest short-day- 'Totem' (Agriculture and Agifood Canada, B.C.); and 6) southern short-day-'Cardinal' (Agricultural Experiment StationArkansas). The hybrids were evaluated in the field at Benton Harbor, Mich.; Becker, Minn.; and Simcoe, Ont.; and data were collected on each plant for gender, date of flowering, percent fruit set, percentage of filled achenes, fruit width, fruit numbers, disease susceptibility [leaf scorch, powdery mildew, and leaf spot, caused by Mycosphaerella fragariae (Tul.) Lindau], and harvest date.

The best-performing genotypes were selected at each site based on these traits and their overall fruiting characteristics. In general, the hybrids were very soft and often irregular in appearance, but displayed a high level of fertility and high flavor, and were productive. Many produced multiple crops. Clones of $F$. virginiana ssp. virginiana yielded much larger fruit than did clones of $F$. virginiana ssp. glauca when crossed with cultivars, and PI 612497 produced the highest number of elite hybrids overall.

Most notable was the high fruit weight observed in the crosses 'Governor Simcoe' x Hemlo 2, 'Chandler' x PI 612497, 'Cardinal' X PI 612501, 'Tribute' x PI 612497, PI 612497 x 'Seascape', 'Seascape' x LH 28-1, 'Seascape' x PI 612499, 251DN107 x PI 612493, and 'Glooscap' $x$ PI 612493. In fact, fruit weights in these hybrids were much higher than their anticipated mid-parent values. These largefruited hybrids may make subsequent improvement more rapid than we anticipated.

When crossed with short-day $F$. Xananassa types, the various cyclic-flowering $F$. virginiana clones produced a wide range in proportions of cyclic-flowering progeny (Table 1). For example, when crossed with the set of short-day cultivars, Hemlo 2 produced no cyclic-flowering progeny, while PI 612496 produced $75 \%$ cyclicflowering progenies. This suggests that several sources of day-neutrality may be available, and that this trait is probably quantitatively inherited. This hypothesis is currently being tested at Michigan State Univ. (MSU) with specific crosses (Sedat Serce, pers. comm.).

We selected the best performing $\mathrm{F}_{1} \mathrm{~s}$ of Dale's crosses and have interbred them at MSU within four families: 1) cyclic-flowering $F$. virginiana $\times$ short-day $F$. ×ananassa; 2 ) short-day $F$. virginiana $\times$ dayneutral $F$. Xananassa; 3 ) cyclic-flowering $F$. virginiana $x$ day-neutral $F$. $\times$ ananassa; and 4) short-day $F$. virginiana $\times$ short-day $F$. ×ananassa. The resulting hybrids were set in the field at Benton Harbor for evaluation, and $\mathrm{an}_{2} \mathrm{~F}_{2}$ population will be generated this winter (A. Dale) utilizing the five best short-day and cyclic-flowering clones selected in Michigan, Minnesota, and Ontario. The resulting hybrids will be evaluated at all three locations.

To date, we have not performed many crosses between $F$. chiloensis and $F$. $\times$ ananassa, as we feel that $F$. chiloensis has been utilized much more than $F$. virginiana in previous breeding. However, a number of elite South American $F$. chiloensis obtained from NCGR, including PI 236579, PI 551736, PI 551959, CFRA 1034, and CFRA 1121, have been hybridized with cultivars of $F$. ×ananassa from the Pacific Northwest ('Redcrest', 'Hood', and 'Totem') in an attempt to generate unique processing types (C. Finn, unpublished data). The best performing progeny will be backcrossed to $F$. chiloensis and individuals

Table 1. Mean percentage of cyclic flowering progeny produced in crosses of native, cyclic-flowering Fragaria virginiana and five short-day $F$. Xananassa cultivars ('Cardinal', 'Chandler', 'Glooscap', 'Governor Simcoe' and 'Totem'). ${ }^{\mathrm{x}}$

\begin{tabular}{lc}
\hline Native clone of $F$. virginiana & Cyclic-flowering progeny $(\%)$ \\
\hline Hemlo-2 & 0 \\
PI 612501 & 6 \\
PI 612499 & 13 \\
LH 10-6 & 21 \\
LH 28-1 & 22 \\
PI 612493 & 34 \\
LH 40-4 & 50 \\
PI 612498 & 56 \\
LH 39-15 & 68 \\
PI 612496 & 75 \\
\hline
\end{tabular}

${ }^{\mathrm{z}}$ Hancock, Dale, and Luby (unpublished data). will be selected that closely represent $F$. chiloensis, but have the higher fruit numbers, color, and size of $F$. ×ananassa.

\section{RECONSTRUCTING FRAGARIA XANANASSA}

We began by selecting a small group of native $F$. chiloensis clones that represented a wide geographical range and were known to carry horticulturally important traits. These included BSP 14, CA 11, PI 551445 and PI 551728 from California; PI 612489 from Oregon; and CFRA 0319, CFRA 0596, PI 612487, CFRA 0883, and PI 612488 from British Columbia. The CFRA numbers from the United States are NCGR numbers, while those from British Columbia are those of the Canadian National Clonal Repository at Smithfield, Ont. PI 551728 has an unusually high reproductive effort for North American $F$. chiloensis and was used as a promising parent at Beltsville, Md., by A. Draper and G. Galletta. CFRA 0319, CFRA 0596, and CFRA 0883 have very large fruit (particularly CFRA 0688) and are probably resistant to powdery mildew. PI 612488 is mildew-susceptible, but has large fruit and is a very fertile hermaphrodite (Dale et al., 1993). CFRA 0883 is a partial hermaphrodite with powdery mildew resistance. CA 11 is resistant to red stele caused by Phytophthora fragariae Hickman, leaf spot, and powdery mildew, and is tolerant to root weevil larvae of Otiorhynchus ssp. (T. Sjulin, pers. comm.). BSP 14 and PI 551445 are resistant to aphids (Chaetosiphon ssp.), two-spotted mites (Tetranychus urticae Koch.), red stele, leaf spot, and powdery mildew. PI 612489 has an unusually high fruit number for $F$. chiloensis.

These wild clones of $F$. chiloensis were hybridized by Adam Dale with our elite group of $F$. virginiana, and $\approx 7000$ hybrids were set in the field at the Ontario, Michigan, and Minnesota sites. Data were collected on each plant for gender, dates of flowering, percent fruit set, percentage of filled achenes, fruit width, fruit number, disease susceptibility (leaf scorch, powdery mildew, and leaf spot), and harvest dates. About 75 elite types were selected for further evaluation. Interestingly, no cyclic-flowering $\mathrm{F}_{1} \mathrm{~s}$ were generated in crosses of cyclic-flowering $F$. virginiana and short-day $F$. chiloensis clones. While fruit size was not as impressive as that of the $F$. virginiana $F$. $\times$ ananassa crosses previously tested, some of the interspecific hybrids had fruit that was larger than would be predicted from the size of their parents. At least one cross, PI $551728 \times$ PI 612497 , produced primary fruit $>2.5 \mathrm{~cm}$ wide in Ontario. The best of these hybrids will ultimately be intercrossed and the resulting hybrids will be tested in Michigan, Minnesota, and Ontario.

\section{BREEDING FRAGARIA CHILOENSIS}

We are concentrating on the land races of $F$. chiloensis (frutilla) developed by the indigenous Chilean people over 1000 years ago (Finn et al., 1998). These land races were widely noted for their size and aromatics, and were dispersed throughout northwestern South America by the Spanish during the conquest. One of these land races, 'The Chili', or 'White Chilean', was part of the accidental formation of $F$. xananassa in Europe 250 years ago.

We are currently crossing four land races with superior combinations of high soluble solids, excellent flavor, strong aroma, large size but poor color and low yields (PI 612316 and PI 236579 from Chile, PI 551736 from Peru, and PI 612318 from Ecuador) with several native clones with either high fruit numbers (PI 612489 from Oregon and PI 602567 from Chile), unusually large fruit size and dark internal color (PI 612490 and PI 551728 from California), or multiple disease resistance (PI 551445 from California). The best performing progeny from these crosses will be subsequently inter-mated to search for even better types. These elite hybrids will also be intermated with elite intercrosses of $F$. virginiana clones to determine if a round of selection will result in superior reconstructions.

\section{DEVELOPING A "SUPERCORE" GERMPLASM COLLECTION}

To develop a baseline for future germplasm evaluations, we have selected a preliminary "supercore" of 38 genotypes, which we feel encompass most of the horticulturally desirable traits described in 
native material from both North and South America (Table 2). We propagated these clones at MSU, and then sent them out to be set in replicated designs at six locations across the United States. The sites were: California (T. Sjulin), Maryland (S. Hokanson and J. Enns), Michigan (J. Hancock and P. Callow), Minnesota (J. Luby), Oregon (C. Finn), and Pennsylvania (B. Goulart and K. Demchak). Data are being collected on fruit size and quality, yield, runner production, flowering and fruiting dates, foliar disease susceptibility, and cold tolerance. In Michigan, we have also planted these selections in methyl bromide-fumigated and nonfumigated soil to assess their resistance to native soil pathogens. In addition, plans are underway to screen this material for heat and drought tolerance (D. Archbold and S. Serce), photosynthetic rate (K. Demchak), and resistance to red stele root rot, anthracnose (Colleotrichum fragariae A.N. Brooks), angular leaf spot caused by Xanthomonas fragariae Kennedy \& King (J. Maas, B. Smith, and S. Hokanson), and northern root-knot nematodes (Meloidogyne hapla Chitwood (J. Pinkerton and C. Finn).

To date, some of the most impressive genotypes are the $F$. chiloensis clones, PI 236579, PI 551735 and PI 551736; and the $F$. virginiana clones, PI 612495, PI 612497, PI 612486, and PI 612323. PI 236579 from Chile is perhaps the most promising $F$. chiloensis clone, showing exceptional yield potential and good resistance to our local foliar pathogens, although it has little apparent tolerance to cold. PI 551735 from Alaska is unusually winter hardy for a $F$. chiloensis clone and has excellent fruit size and quality. PI 551736 from Peru has very long peduncles, large fruit, and some winter hardiness. PI 612323 from North Carolina has very soft fruit, but is very large-fruited and highyielding, with relatively disease-free leaves. PI 612486 from North Carolina has proven particularly resistant to foliar diseases in Maryland. PI 612497 from Ontario is very resistant to foliar diseases and is the largest-fruited $F$. virginiana ssp. virginiana clone from the Midwest. PI 612495 from the Rocky Mountains has the largest fruit and highest vigor of all the $F$. virginiana ssp. glauca [(S. Watson) Staudt] clones collected from the Rockies. PI 612495, PI 551735, and PI 612323 may also be resistant to soil pathogens, as they produced similar numbers of runners and fruit on fumigated and nonfumigated soil in Michigan. PI 612318 from Huachi Grande, Ecuador, has proven to be very large-fruited in the greenhouse, but unfortunately is very tender to both cold and heat in the field, as previously indicated by Darrow (1966).

As a supplement to this work, we are evaluating a large portion of the native strawberry collection of NCGR. The total collection consists of 275 native clones, representing most of the geographic range of the octoploid species in North and South America. In conjunction with Son Phan, a visiting scientist from Hanoi Univ., we have been collecting data on a wide range of horticulturally important characteristics, diagnostic taxonomic traits, and randomly amplified polymorphic DNA (RAPD) variation. Our primary goal is to determine how closely our supercore group represents the total diversity of native octoploids, but we are also interested in finding new elite types that might be incorporated into the supercore. We believe that any elite germplasm collection should be considered fluid, with genotypes being added and subtracted as new types that better encompass the available diversity are identified.

\section{CONCLUSIONS}

We expect this work to generate a catalogue of elite representatives of octoploid strawberries, and to document their utility in germplasm enhancement and breeding. While numerous screens of native germplasm have been made in the past, only limited samples of the two species have actually been utilized, usually in the background of $F$. xananassa. This has reduced the probability of uncovering unique and valuable gene combinations.

There are reports that $F$. virginiana has a strong negative impact on fruit size and firmness (Darrow, 1966; Scott, 1959), but we expect that at least some of the germplasm we have identified has far superior horticultural characteristics than to those of previously used clones. Our recent experience indicates that large-fruited $\mathrm{F}_{1}$ hybrids can indeed be recovered in $F$. virginiana $\times F$. Xananassa crosses, and Bringhurst and Voth (1984) have shown that only three backcross generations are required to recover fruit of commercial size after hybridizations with $F$. virginiana ssp. glauca. Dramatic improvement in fertility has also been demonstrated within three generations of recurrent selection within $F$. virginiana (Luby et al., 1995).

We are confident that our systematic evaluation program will yield new, useful breeding parents with unique combinations of genes. Progress was rapid after the uncontrolled hybridizations of almost randomly selected $F$. virginiana and $F$. chiloensis over 250 years ago, and the conscious unification of elite native types should yield even more rapid progress. The success of the native Chileno peoples in improving $F$. chiloensis without modern breeding techniques is particularly worthy of note.

Table 2. A preliminary supercore collection of octoploid strawberries. Genotypes are denoted by the plant introduction (PI) number of the U.S. National Plant Germplasm System. Also listed in parentheses are the CFRA numbers of the National Clonal Germplasm Repository at Corvallis, Ore., and the names or initials used by the original collectors. Germplasm Resources Information Network/National Genetic Resources Program (GRIN/NGRP) Accession Information is available at http://www.ars-grin.gov

\section{F. chiloensis = North America}

PI 551445 (CFRA 34; Redwood Creek Park-37; RCP-37)—Male; short-day; resistant to aphids, two-spotted spider mites, red stele, leaf spot, powdery mildew, and root lesion nematodes; representative of ssp. lucida from northern California (Hancock and Bringhurst, 1979; Potter and Dale, 1994; Sjulin, pers. comm.).

PI 551453 (CFRA 42; Westport Light House State Park-08)—Female; shortday; resistant to red stele and strawberry aphid; representative of ssp. lucida from the lower Pacific Northwest (Washington) (GRIN/NPGS Accession Information).

PI 551459 (CFRA 48; Brandon State Park-14; BSP-14)—Male; short-day; resistant to aphids, two-spotted spider mites, red stele, spot and mildew; representative of ssp. pacifica from the lower Pacific Northwest (Oregon) (GRIN/NPGS Accession Information; Crock et al., 1982).

PI 551728 (CFRA 357; Pigeon Point; CA 1367)—Hermaphrodite; short-day; very large fruit; high flavor and brix; transmits at least modest winter hardiness as was a good parent in combination with $F$. Xananassa at Beltsville, Md.; found on dry headland scrub, so probably has high salt and drought tolerance as well as low nutrient needs; high photosynthetic rate; may be resistant to Verticillium wilt; representative of ssp. lucida from central California(Bringhurst et al., 1966; Draper and Galletta, pers. comm.; GRIN/NPGS Accession Information; Hancock and Bringhurst, 1979; Hancock et al., 1989).

PI 551735 (CFRA 368; Auke Lake, CA 1499)—Female; short-day; relatively large and high flavored; probably very winter hardy due to it's location; free of all foliar diseases in native site; representative of $F$. chiloensis ssp. pacifica from upper northwestern range of $F$. chiloensis (Alaska) (GRIN/NPGS Accession Information).

PI 612487 (CFRA 1689²)—Female; short-day; large fruit; winter hardy in Ontario, but not Michigan; very resistant to leaf scorch and spot; representative of ssp. pacifica from the upper Pacific Northwest (British Columbia) (Dale and Luffman, pers. comm.; Luffman and MacDonald, 1993)

PI 612488 (CFRA 1690y) —Hermaphrodite; short-day; large orange fruit; winter hardy in Ontario, but not Michigan; elite representative of ssp. pacifica from the upper Pacific Northwest (British Columbia) (Dale and Luffman, pers. comm.; Luffman and MacDonald, 1993).

PI 612489 (CFRA 1691; HM1)-Female; short-day; unusually high fruit number; representative of ssp. lucida from the lower Pacific Northwest (Oregon) (Sjulin, pers. comm.)

PI 612490 (CFRA 1692; Franklin Point; Scotts Creek; S.C.)-Female; shortday; large, red fruit; highest yield potential of any North American clone analyzed to date; found on dunes, so probably has high salt and drought tolerance, as well as low nutrient needs; elite representative of ssp. pacifica from central California (Hancock and Bringhurst, 1979, 1988).

\section{F. chiloensis = South America}

PI 236579 (CFRA 24; 'Round Red Chilean'; Darrow 72; D-72)—Hermaphrodite; short-day; large fruit; collected by Darrow as a representative of the redfruited land races of $F$. chiloensis grown in Chile (GRIN/NPGS Accession Information)

PI 551736 (CFRA 372; CA 1541)—Hermaprodite; short-day; very large fruited; reddish; probably has good winter hardiness as it was grown at 4000m elevation; collected by Bringhurst as a representative of the red fruited land races of $F$. chiloensis grown in Peru (GRIN/NPGS Accession Information) PI 552091 (CFRA 796; Termas de Chillan; TDC; Jim 2)-Hermaphrodite; short-day; probably has good winter hardiness as grows at 1900-m elevation;

Continued on next page 
$\overline{\text { representative of the biggest red-fruited population of native f. patagonia we }}$ have seen in Chile (Cameron et al., 1993; GRIN/NPGS Accession Information). PI 602567 (CFRA 1075; 2 MAR 1A; 2 Puerto Raúl Marín Balmaceda 1A) Hermaphrodite; short-day; reddish fruit; unusually high number of inflorescences; high photosynthetic rate; located on dunes so is probably salt and drought tolerant, as well as having low nutrient needs; representative of native f. patagonica from Región XI in Chile (Cameron et al., 1993; GRIN/NPGS Accession Information; Lavín, 1996)

PI 602568 (CFRA 1100; 2 Palena 2C; 2 PAL 2C)—Female; short-day; red fruit; may have some winter hardiness as found at 600-m elevation; high soluble solids, found in forest with high organic matter; representative of native $\mathrm{f}$. patagonia from Región X in Chile (Cameron et al., 1993; GRIN/NPGS Accession Information; Lavín, 1997)

PI 602570 (CFRA 1108; 2 Lago General Carrera 3B; 2 CAR 3B)-Hermaphrodite; short-day; red fruit; one of the southern most coastal plants of $\mathrm{f}$. patagonia from Región XI in Chile (Cameron et al., 1993; GRIN/NPGS Accession Information; Lavín, 1997).

PI 612316 (CFRA 1088; 2 BRA 1A; 2 Mar Brava 1A)—Hermaphrodite; large white fruit; high soluble solids; representative of the old, white-fruited land races of $F$. chiloensis still found in Región XI in Chile (Cameron et al., 1993; GRIN/NPGS Accession Information; Lavín, 1997).

PI 612317 (CFRA 1092; 2 La Tapera 4B; 2 TAP 4B)—Female; short-day; large red fruit; may have some winter hardiness as found at $600 \mathrm{~m}$ elevation; unusually high number of inflorescences; high soluble solids; may have low nutrient and water needs as found on sand dunes, representative of native $\mathrm{f}$. patagonia from Región XI in Chile (Cameron et al., 1993; GRIN/NPGS Accession Information; Lavín, 1997).

PI 612318 (CFRA 1480; NAH 3) —-Hermaphrodite; short-day; reddish; probably the largest fruited land race in the world; collected at Huachi Grande (near Ambato), Ecuador (Darrow, 1957; Finn et al., 1998; GRIN/NPGS Accession Information; Popenoe, 1921 ).

\section{Fragaria virginiana $=$ North America}

PI 551471 (CFRA 58; Ice House-59)—Partial hermaphrodite; cyclic flowering, red-fruited , probably winter-hardy as from high elevation near tree line; representative of ssp. platypetala from the Sierra Nevada Mountains (California) (GRIN/NPGS Accession Information; Hancock and Bringhurst, 1979).

PI 551527 (CFRA 110)—Partial hermaphrodite; randomly picked from Repository Collection as representative of ssp. platypetala from the Cascade Mountains (Oregon) (GRIN/NPGS Accession Information).

PI 612320 (CFRA 1455; JP 95-9-6) - Hermaphrodite; large fruit; very long, erect peduncles; tolerant to $C$. acutatum, leaf scorch, and powdery mildew; representative ssp. virginiana from the southern United States (Georgia) (Ballington, pers. comm.; GRIN/NPGS Accession Information).

PI 612323 (CFRA 1557; NC 96-35-2)—Female; large fruit; resistant to $C$. acutatum, leaf scorch, and leaf blight; tolerant to powdery mildew; representative of ssp. virginiana from the southern United States (Alabama) (Ballington, pers. comm.; GRIN/NPGS Accession Information).

PI 612324 (CFRA 1580; NC 96-48-1) -Female, high productivity; erect peduncles, resistant to $C$. acutatum and powdery mildew; tolerant to leaf scorch and leaf blight; representative of ssp. virginiana from the southern United States (South Carolina) (Ballington, pers. comm.; GRIN/NPGS Accession Information).

PI 612325 (CFRA 1620; NC 96-5-3)—Partial hermaphrodite; very high productivity; erect peduncles; resistant to leaf scorch and powdery mildew; tolerant to leaf blight; representative of ssp. virginiana from the southern United States (North Carolina) (Ballington, pers. comm.; GRIN/NPGS Accession Information).

PI 612486 (CFRA 1408; NC 95-19-1)—Female; high productivity; firm fruit; resistant to $C$. acutatum and leaf scorch; tolerant to leaf blight and powdery mildew; representative of ssp. virginiana from the southern US (Mississippi) (Ballington, pers. comm.; GRIN/NPGS Accession Information).

PI 612491 (CFRA 1693; BH3; BT3; CA 1226)—Female; repeat flowering; red-fruited; probably winter-hardy as found at 2000-m elevation; collected in 1998 at Big Cottonwood Canyon, in the Brighton Mountains, but probably represents the clone used by by Bringhurst (FRA 338) to produce day-neutral cultivars; representative of ssp. glauca from the Rocky Mountains (Utah) (Bringhurst and Voth, 1978; GRIN/NPGS Accession Information)

PI 612492 (CFRA 1694; Eagle 14)—Partial hermaphrodite; weak, cyclic flowering; resistant to mildew and scorch; representative of ssp. virginiana from south central Canada (Ontario) (Dale, pers. comm.; Dale et al., 1993) PI 612493 (CFRA 1695; Frederick 9)-Male; cyclic flowering; winter hardy; resistant to mildew and scorch; representative of spp. virginiana from southcentral Canada (Ontario) (Dale, pers. comm.; Dale et al., 1993)

PI 612494 (CFRA 1696; LH5; BH2)—Female; cyclic flowering; probably winter-hardy as found at 1550-m elevation; representative of an apparent

Continued at top of next column
Table 2. Continued.

hybrid between eastern ssp. virginiana and western ssp. glauca on the western edge of the Rocky Mountains (Black Hills of South Dakota) (Hancock and Luby, 1991, Luby et al., 1992; Sakin et al., 1997).

PI 612495 (CFRA 1697; LH 50-4)—Hermaphrodite; cyclic-flowering; extremely large, numerous fruit; probably cold winter-hardy as found at $2255-\mathrm{m}$ elevation; representative of an apparent hybrid between ssp. glauca and ssp. virginiana on the western edge of the Rocky Mountains (Lewis and Clark National Forest, Montana) (Hancock and Luby, 1991; Hancock, unpublished; Luby et al., 1992; Sakin et al., 1997).

PI 612496 (CFRA 1698; N 8688; RH 43)-Partial hermaphrodite; cyclic flowering; resistant to black root rot; representative of ssp. glauca from the upper northwestern part of $F$. virginiana's range (Alaska) (Luby, pers. comm. Luby and Stahler, 1993)

PI 612497 (CFRA 1699; Montreal River 10)—Hermaphrodite; short-day; unusually large fruit; resistant to mildew and scorch; representative of ssp virginiana from south-central Canada (Ontario) (Dale, pers. comm.; Dale et al., 1993).

PI 612498 (CFRA 1700; MS 31-19; RH 23)—Partial hermaphrodite; cyclic flowering; large fruit; resistant to black root rot, scorch, and leaf spot; representative of ssp. virginiana from the upper Midwest (Minnesota) (Luby, pers. comm.; Luby and Stahler, 1993)

PI 612499 (CFRA 1701; MS 05-06; RH 30)-Partial hermaphrodite; cyclic flowering; resistant to black root rot, scorch, and leaf spot, representative of ssp. virginiana from the upper Midwest (Minnesota) (Luby, pers. comm.; Luby and Stahler, 1993)

PI 612500 (CFRA 1702; N 8418; RH45)—Partial hermaphrodite; weak cyclicflowering; probably extremely cold-hardy due to location; resistant to black root rot, scorch, and leaf spot; representative of ssp. glauca from southwestern Canada (Alberta) (Luby, pers. comm.; Luby and Stahler, 1993).

PI 612501 (CFRA 1703; LH 30-4)—Hermaphrodite; cyclic-flowering; largefruited; heat-tolerant; representative of ssp. glauca from the central Rocky Mountains (Montana) (Hancock and Luby, 1991; Hancock et al., 1995; Luby et al., 1992; Sakin et al., 1997)

PI 612569 (CFRA 1414; NC 95-21-1)—Female; high productivity; tolerant to C. acutatum; resistant to leaf scorch, leaf blight, and powdery mildew; representative of ssp. virginiana from southern United States (Mississippi) (Ballington, pers. comm.; GRIN/NPGS Accession Information).

PI 612570 (CFRA 1435; JP 95-1) - Partial hermaphrodite; resistant to C. acutatum; representative of ssp. virginiana from the southern United States (Florida) (Ballington, pers. comm.; GRIN/NPGS Accession Information).

${ }^{\mathrm{z}}$ Also listed as CFRA 688 in the Canadian Clonal Genebank in Smithfield, Ontario.

${ }^{y}$ Also listed as CFRA 1267 in the Canadian Clonal Genebank in Smithfield, Ontario.

\section{Literature Cited}

Bringhurst, R.S. and V. Voth. 1978. Origin and evolutionary potentiality of the day-neutral trait in octoploid Fragaria. Genetics 90:510.

Bringhurst, R.S and V. Voth. 1984. Breeding octoploid strawberries. Iowa State J. Res. 58:371-381.

Bringhurst, R.S., S. Wilhelm, and V. Voth. 1966. Verticillium wilt resistance in natural populations of Fragaria chiloensis in California. Phytopathology 51:786-794.

Cameron, J.S., T.M. Sjulin, J.R. Ballington, C.H. Shanks, C. Munoz, and A Lavín. 1993. Exploration, collection and evaluation of Chilean Fragaria: Summary of 1990 and 1992 expeditions. Acta Hort. 348:65-74.

Crock, J.E., C.H. Shanks, and B.H. Barritt. 1982. Resistance in Fragaria chiloensis and $F$. Xananassa to the aphids Chaetosiphon fragaefolii and $C$. thomasi. HortScience 17:959-960.

Dale, A., H.A. Daubeny, M. Luffman, and J.A. Sullivan. 1993. Development of Fragaria germplasm in Canada. Acta Hort. 348:75-80.

Dale, A. and T.M. Sjulin. 1990. Few cytoplasms contribute to North American strawberry cultivars. HortScience 25:1341-1342.

Darrow, G.M. 1957. The Ambato strawberry of Ecuador. Fruit Var. Hort Digest 12:5-7.

Darrow, G.M. 1966. The strawberry. History, breeding and physiology. Holt Rinehart and Winston, New York.

Finn, C., J. Hancock, and C. Heider. 1998. Notes on the strawberry of Ecuador: Ancient land races, the community of farmers and modern production. HortScience 33:583-587.

Hancock, J.F. 1999. Strawberries. CABI Publishing, Wallingford, Oxon, U.K.

Hancock, J.F. and R.S. Bringhurst. 1979. Ecological differentiation in perennial species of Fragaria. Amer. J. Bot. 66:367-375.

Hancock, J.F. and R.S. Bringhurst. 1988. Yield component interactions in wild populations of California Fragaria. HortScience 23:889-890. 
Hancock, J., A. Dale, and J.J. Luby. 1993. Should we reconstitute the strawberry. Acta Hort. 348:86-93

Hancock, J.F., J.A. Flore, and G.J. Galletta. 1989. Gas exchange properties of strawberry species and their hybrids. Scientia Hort. 40:139-144.

Hancock, J.F. and J.J. Luby. 1991. Collection of Fragaria and other small fruit genera in the northern Rocky Mountains, USA. Res. Rpt. 511, Michigan State Univ. Agr. Expt. Sta., East Lansing.

Hancock, J.F. and J.J. Luby. 1995. Adaptive zones and ancestry of the most important North American strawberry cultivars. Fruit Var. J. 49:85-89.

Hancock, J.F., J.L. Maas, C.H. Shanks, P.J. Breen, and J.J. Luby. 1990. Strawberries (Fragaria ssp.). Acta Hort. 290:489-546.

Hancock, J.F., M. Sakin, J.J. Luby, A. Dale, and R.L. Darnell. 1995. Germplasm resources in octoploid starwberries: Potential sources of genes to increase yield in northern climates, p. 87-94. In: M.P. Pritts, C.K. Chandler and T.E. Crocker (eds.). Proc. IV North Amer. Strawberry Conf., Univ. of Florida, Gainesville.

Hokanson, K., R.E. Harrison, J.J. Luby, and J.F. Hancock. 1993. Morphological variation in Fragaria virginiana from the Rocky Mountains. Acta Hort. 348:94-101.

Lavín, A. 1997. Caracterización botánica, fisilógica y agronómica de ecotipos Chilenos de Fragaria chiloensis (L.) Duch., Recolectados en las X y XI regiones de Chile. Informe Final, Proyecto Fondecyt 1940083 (1996).

Luby, J.J., J.F. Hancock, and J.R. Ballington. 1992. Collection of native strawberry (Fragaria ssp.) germplasm in the Pacific Northwest and Northern Rocky Mountains of the USA. HortScience 27:12-17.

Luby, J.J., J.F. Hancock, and J.S. Cameron. 1991. Expansion of the strawberry germplasm base in North America, p. 66-75. In: A. Dale and J. Luby (eds.).
The strawberry into the 21st century. Timber Press, Portland, Ore.

Luby, J.J., R.E. Harrison, G. Furnier, and J.F. Hancock. 1995. Germplasm resources for strawberries: Morphological traits, p. 95-102. In: M.P. Pritts, C.K. Chandler and T.E. Crocker (eds.). Proc. IV North Amer. Strawberry Conf., Univ. of Florida, Gainesville.

Luby, J.J. and M. Stahler. 1993. Collection and evaluation of Fragaria virginiana in North America. Acta Hort. 345:49-54.

Luffman, M. and P.J. MacDonald. 1993. Fragaria germplasm at the Canadian Clonal Genebank. Acta Hort. 348:102-108.

Moore, P.P., T.M. Sjulin, and C.H. Shanks, Jr. 1995. 'Puget Reliance” strawberry. HortScience 30:1468-1469.

Popenoe, W. 1921. The frutilla, or Chilean strawberry. J. Hered. 12:457-466.

Potter, J.W. and A. Dale. 1994. Wild and cultivated strawberries can tolerate or resist root-lesion nematode. HortScience 29:1074-1077.

Sakin, M., J.F. Hancock, and J.J. Luby. 1997. Identifying new sources of genes that determine cyclic flowering of Fragaria virginiana ssp. glauca Staudt. J. Amer. Soc. Hort. Sci. 122:205-210.

Scott, D.H. 1959. Size, firmness and time of ripening of fruit of seedlings of Fragaria virginiana Duch. crossed with cultivated strawberry varieties. Proc. Amer. Soc. Hort. Sci. 74:388-393.

Sjulin, T.M. and A. Dale. 1987. Genetic diversity of North American strawberry cultivars. J. Amer. Soc. Hort. Sci. 112:375-385.

Staudt, G. 1999. Systematics and geographic distribution of the American strawberry species: Taxonomic studies in the genus Fragaria (Rosaceae: Potentilleae). Univ. of California Publ. in Botany, Vol. 81.

Wilhelm, S. and J.E. Sagen. 1974. A history of the strawberry from ancient gardens to modern markets. Div. of Agr. Sci., Univ. of California, Berkeley. 